\title{
Chicken suits and other aspects of situated credibility contests: Explaining local trajectories of anti-minority activism
}

\begin{abstract}
Why do some towns become focal points for anti-minority activism at particular moments in time, when other towns with similar socio-economic conditions do not? While policy practitioners charged with responding to such activity frequently ask this question, it has received less academic attention. Consequently, an adequate response falls between different strands of the academic literature on antiminority politics.
\end{abstract}

We explore this question through a comparative analysis of how and why Luton, a Bedfordshire town, became a focal point for the latest wave of organised antiminority activism in the UK, centred around the English Defence League (EDL), while Blackburn with Darwen, a local authority in Lancashire with a history of extreme right political 'successes', did not.

We develop the concept of situated credibility contests to help us articulate the contingent relationships between potential explanatory variables and political outcomes, and describe how 'demand-side' and 'supply-side' variables interact through the strategic actions of anti-minority activists and their opponents.

Keywords: English Defence League, credibility contests, mobilisation, antiminority activism, extreme right

\section{Introduction}

Why do some towns become focal points for anti-minority activism ${ }^{1}$ at particular moments in time? While policy practitioners charged with responding to such activity

\footnotetext{
${ }^{1}$ We use 'anti-minority politics' and 'anti-minority activism' as hypernyms to include all forms of activism explicitly targeting minority groups. It encompasses a broad range of ideologically distinct groups ranging from the ostensibly single-issue 'anti-Muslim' politics of the EDL to the racial nationalism of extreme right formations like the BNP and NF.
} 
frequently ask this question, an adequate response falls between three strands of the academic literature on organised anti-minority politics. First, there are local case studies, often informed by detailed ethnographic research (Hewitt 2005; Husbands 1983; Rhodes 2009; Roy 1993). These provide valuable insight into how anti-minority politics gains and sustains traction through local struggles over power, recognition and opportunity, and the linking of local narratives and symbols with more abstract ideas about in-groups and out-groups, threats and opportunities. Yet they rarely use cross-locality comparisons to test the hypotheses they generate. Hypothesis testing is further stymied by the fact that the case studies are invariably places where anti-minority activism gained momentum, rather than where it stalled.

Second, there is a well-established literature on spatial patterns of support for antiminority politics (Biggs \& Knauss 2012; Ford \& Goodwin 2010; Kaufmann \& Harris 2015). This research, which plots such support against demographic, economic and political variables, is inherently comparative and highlights the structural conditions conducive to anti-minority politics. Yet it reveals little about the mechanisms through which certain configurations of structural 'drivers' translate into support for or participation in anti-minority politics, and less still as to why on other occasions they do not. Reliance upon polling data also make such approaches less suited to capturing 'subpolitical' (Hewitt 2005) forms of anti-minority activism.

Third, a recent turn to the literature on social movements has provided a more theorized understanding of anti-minority activism and a less caricatured account of antiminority activists (Caiani et al 2012; Klandermans \& Mayer 2006). It provides insight as to how and why anti-minority activism sometimes veers towards more radical strategies of action (Caiani \& Borri 2013; Macklin \& Busher 2015); how anti-minority activists respond to and create political or discursive opportunities (Koopmans \& Muis 2009); the 
pathways through which individuals enter and leave anti-minority activism (Blee 2003; Linden \& Klandermans 2007); the emotional dynamics of anti-minority politics (Busher 2015; Pilkington 2016; Virchow 2007); and the role of cultural (re)production in promulgating support (Miller-Idriss 2017; Simi \& Futrell 2010). Yet with respect to our question, this literature suffers from similar limitations to that on the local dynamics of anti-minority activism. Comparative analysis is almost always cross-national (Caiani \& Borri 2013; Klandermans \& Mayer 2006; Macklin \& Virchow 2011) or occasionally cross-regional (De Witte \& Klandermans 2000) rather than cross-local. It also tends, with few exceptions (e.g. De Witte \& Klandermans 2000), to focus on cases where mobilisation has gained momentum, rather than where it has not.

In this article we attempt to make inroads into this limitation in the literature. We do this through a comparative case study of two English towns with broadly comparable socio-economic and political conditions that have experienced different trajectories of anti-minority activism: Luton, a Bedfordshire town thirty miles northwest of London, which became and remained a focal point for the most recent wave of organised antiminority activism in the UK, spearheaded by the English Defence League (EDL); and Blackburn with Darwen (hereafter Blackburn), a Lancashire town twenty-five miles northwest of Manchester, where this wave of anti-minority politics initially gained, but then lost, momentum.

We develop our analysis using the concept of situated credibility contests adapted from Joseph Nye's observation that all forms of politics are, ultimately, 'a contest of competitive credibility' (Nye 2011, p. 106). Theoretically grounded in a 'strategic perspective' (Jasper 2004) of mobilization, we use this concept to apply an understanding of contentious politics as involving a range of 'players', more or less tightly entrained with one another, engaged in an open-ended series of strategic decisions and moves 
within a series of 'arenas' that shape, and are shaped by, the interactions that take place within them (Jasper \& Duyvendak 2015). Through these moves, players seek to enhance their own credibility and/or undermine that of their opponents in the eyes of the audiences they consider most relevant to the fulfilment of their objectives (Gieryn 1999). This might entail opposing actors competing directly for similar forms of credibility e.g. claims to speak for 'ordinary English people' in the town. At other times, the contest might be asymmetric: while EDL activists sought to undermine the credibility of local authorities' claims to be governing in the interests of all residents, they did not seek to replace them directly.

The availability and value of symbolic materials that the players might draw on in the arenas across which the contest takes place is shaped by local history and the production of local social memory and identity (Hewitt 2005), albeit local social memory and identity is produced in dialogue with regional, national or global developments (Zerubavel 1999). For example, how a town is situated within national debates about specific social problems might shape local social cognition about the nature and significance of those problems. Our basic contention is that where anti-minority activists are able to enjoy some successes within these situated credibility contests, they are more likely to gain traction and the town is more likely to become a focal point for anti-minority activism.

We believe the concept of situated credibility contests has several strengths as a 'thinking tool' (Bourdieu in Wacquant 1989, 50). First, it provides an effective mechanism for integrating 'demand side' explanations of the success or failure of organised anti-minority politics, which emphasise the psycho-social, discursive and structural drivers of support, and 'supply side' explanations, which emphasise how such movements build support through tactical, ideological or communicative innovations or 
the personal charisma of leaders (Goodwin 2006; Mudde 2010; Muis \& Immerzeel 2017; Rydgren 2007). While most scholars emphasise the importance of both, they are still largely treated as distinct but complementary explanations (Golder 2016). By contrast, the concept of situated credibility contests focuses analytic attention on how different variables interact through players' strategic choices as they seek to outmanoeuvre one another. In this article, for example, we use the concept to tease out the interdependence of four basic sets of variables in shaping the trajectory of organised anti-minority activism in the case study towns: potential catalytic events; socio-economic and political conditions; the local processes of anti-minority mobilisation; and the responses of those who sought to manage this wave of anti-minority politics.

Second, the emphasis on how variables interact through players' strategic choices lends itself to rendering the inherent conditionality of the relationship between any one potential explanatory variable and political outcomes. The fact that variables are conceived of as interacting through the unfolding contest also encourages attention to the temporal dimension of such conditionalities - to the sequencing of events over time currently an under-researched dimension of anti-minority politics (Golder 2016)

Third, the idea of a credibility contest encourages that 'equal and symmetric weight' be given to those involved in anti-minority politics and 'the other players whom they engage' (Jasper 2015, 9). Whereas within the existing literature both supply and demand side factors tend to be discussed as they relate to the anti-minority actors, ${ }^{2}$ the concept of situated credibility contests encourages discussion of those factors as they apply to the contest.

\footnotetext{
${ }^{2}$ See for example analyses of how 'discursive opportunities' shape the trajectories of anti-minority politics (Koopmans \& Muis 2009).
} 
The following section introduces the EDL and the wave of anti-minority activism that evolved from it. We then describe the case study towns and research methods before presenting and discussing the research findings.

\section{The national context}

The EDL emerged from a series of demonstrations in Luton, following an incident on 10 March 2009 in which activists from a radical Islamist group, Ahlus Sunnah wal Jamaah $(\mathrm{ASWJ}),{ }^{3}$ disrupted a homecoming parade by the Royal Anglian Regiment, recently returned from Iraq. Incensed, a group of residents proposed a demonstration calling on Luton Council to act against such groups. When the council refused their application for a march, a group calling itself United People of Luton (UPL) announced a 'Reclaim our Streets' march for 13 April. Approximately 150-200 people attended: a mixture of angry locals and football ultras from across southern and central England. There were six arrests. UPL staged another demonstration the following month, resulting in widespread public disorder (Copsey 2010). From these events emerged a national network of activists who formed the EDL on 27 June 2009, ostensibly to protest against the spread of 'militant Islam'. After initial small-scale demonstrations in London and Birmingham, it quickly gathered momentum. By the autumn, EDL demonstrations across the country regularly attracted in excess of 1,000 people, sustained by a network of local 'divisions' and considerable social media support. ${ }^{4}$

The EDL heralded a new wave of anti-minority activism in the UK, organisationally and ideologically distinct from traditional extreme right groups such as

\footnotetext{
${ }^{3}$ A successor to the proscribed Al-Muhajiroun.

${ }^{4}$ At several points, the EDL's Facebook following exceeded 100,000.
} 
the British National Party (BNP), albeit with some important overlaps in terms of issue frames and personnel. Although Tommy Robinson, who led the EDL with his cousin, Kevin Carroll, was previously a BNP member, they made clear from the outset their unwillingness to ally with the BNP (Copsey 2010). Furthermore, while the EDL protest narrative resonated with some extreme right positions regarding nationalism and the supposed threat of Muslims and Islam, there were important differences, including its rejection of biological racism. Indeed, the EDL styled itself as an 'anti-racist' organisation - a claim many activists made sincerely (Busher 2017; Pilkington 2016). Tactically, while the BNP had prioritised party-based organisation and electioneering over marching, the EDL embraced street-based activism and favoured a fluid social movement structure: operating through a loose and often chaotic network of local divisions without formal membership and with porous group boundaries (Copsey 2010).

The EDL began losing momentum from mid-2011 amidst protest fatigue, mounting legal charges against activists (usually for public disorder offences), intramovement ideological and tactical differences, factional rivalries and personal grudges (Busher 2015, 123-56). The energy of this wave of activism has been slow to dissipate, however. While the EDL largely collapsed, particularly after the departure of Robinson and Carroll in October 2013, the movement fragmented into a plethora of groups including, of most relevance to this article, the North-West Infidels (NWI). As of 2018, such groups continue to maintain their online presence and to demonstrate, albeit on a greatly diminished basis. Meanwhile, other groups mobilising around cognate issues, but without their roots in the EDL, have also emerged, such as Britain First, which formed initially as an offshoot from the BNP and has carried out protest actions in both Luton and Blackburn. 


\section{Methodology}

\section{Case study selection}

We developed a comparative case study to integrate the strengths of the three aforementioned strands of literature on organised anti-minority politics - deep analysis of local political and sub-political struggles; cross-case comparison of structural conditions and a dynamic understanding of mobilization and counter-mobilization. ${ }^{5}$ Such an approach is not without challenges. Foremost among these is case selection, where variation along relevant dimensions must be offset against variation along other dimensions as well as consideration of practical concerns, such as access issues (Seawright \& Gerring 2008).

Luton's inclusion in the study was largely beyond the research team's control. The research was commissioned by a network of local authorities. ${ }^{6}$ Members of that network had identified Luton as a town of particular interest because it had become a national focal point for this wave of anti-minority activism. By 'focal point' we mean:

1. It was a site of regular, and at times substantial, anti-minority protest. Following the EDL's formation, two major demonstrations occurred in Luton in February 2011 and May 2012. While figures are disputed, the 2011 demonstration was the EDL's largest, attracting over 3,000 participants. A further demonstration in 2014 attracted 300-400 participants. Demonstrations

\footnotetext{
${ }^{5}$ Financial and logistical constraints meant we were unable to extend beyond two case studies without compromising case study depth and detail.

${ }^{6}$ The Special Interest Group on Far Right Activity, sponsored by the UK Department for Communities and Local Government.
} 
aside, local activists frequently undertook actions, including protesting against a charity football match raising money for $\mathrm{Gaza}^{7}$, at the opening of Luton's Discover Islam Centre, and intervening in local debates about other policy issues such as town planning. Subsequently, Britain First has also conducted inflammatory events in the town, including a series of mosque 'invasions' in 2014 and a 'Christian Patrol' through the largely Muslim Bury Park, in January $2016 .^{8}$

2. It was prominent in the protest narratives of groups at the forefront of antiminority activism nationally and internationally. Luton is repeatedly referenced on websites associated with the so-called counter-jihad movement, such as Jihad Watch or the Gates of Vienna, to support arguments about a supposed clash of civilisations; during his trial in 2012, Anders Breivik referred to Luton as having 'war-like conditions' and 'Islamic no-go zones', and Luton has recently been visited by prominent North American activists associated with Generation Identity. ${ }^{10}$

3. Anti-minority activists operating in the town have, as a minimum, gained some sympathy among sections of the local population beyond core activists. Although the EDL as an organisation never sought election, making it difficult

${ }^{7}$ http://www.lutontoday.co.uk/news/crime/residents-fears-over-edl-s-plans-to-march-at-charity-event-1$\underline{5411060}$ [Accessed 22/06/17].

${ }^{8}$ https://www.lutontoday.co.uk/news/crime/tempers-flare-as-britain-first-holds-christian-patrol-in-burypark-1-7178541 [Accessed 22/06/17]. A 'Christian Patrol' in 'Muslim-occupied Blackburn' failed to resonate, http://www.huffingtonpost.co.uk/2015/01/21/britain-firsts-blackburn-christian-patroln_6513980.html [Accessed 22/06/17].

${ }^{9}$ http://metro.co.uk/2012/04/18/anders-behring-breivik-attacks-war-like-luton-during-norway-trial392568/ [Accessed 12/03/2018]

${ }^{10}$ https://www.lutontoday.co.uk/news/far-right-activist-denied-entry-to-uk-after-distributing-racistmaterial-in-luton-1-8411543 [Accessed 12/03/2018] 
to gauge popular support, there is evidence that its brand of anti-minority politics gained some traction. In 2012 Carroll ran for Police and Crime Commissioner on behalf of the British Freedom Party, at the time operating in a loose alliance with the EDL. He polled 10.6 per cent of the vote $(8,676$ votes) across Central Bedfordshire. And while some of the focus group participants (see below) were critical of Robinson and the EDL, members of the research team saw Robinson greeted and high-fived by members of the public as he walked around Luton.

4. Local public authorities perceived anti-minority activists to represent a significant challenge. During interviews and informal conversations, council and police officers working in different policy areas reported concern about how EDL activists might respond to policy decisions, and some mused in private that parts of the local statutory authorities had occasionally been 'given the run-around' by Robinson and Carroll.

Furthermore, local authority staff had agreed to facilitate the project. For comparison, we required a town where there were known to have been concerted efforts to foment support for this wave of anti-minority activism, but where such efforts appeared to have stalled. We also sought a town broadly similar to Luton in terms of socio-economic indicators identified elsewhere as relevant to patterns of support for anti-minority politics.

While Blackburn $(147,489 \text { inhabitants })^{11}$ is smaller than Luton $(203,201$ inhabitants), it was one of a number of towns identified as having a similar-enough socioeconomic profile to bear comparison. Both Luton and Blackburn have experienced industrial decline; they had identical levels of unemployment $(8.3 \%$ of the working age

\footnotetext{
${ }^{11}$ All demographic data is derived from the 2011 census.
} 
population), well above the national average (5.6\%); significant deprivation (using the Carstairs Index, out of 378 local authorities in England and Wales, Luton ranked $25^{\text {th }}$ most deprived and Blackburn $\left.44^{\text {th }}\right) ;{ }^{12}$ and both had become more ethnically diverse at a rate in excess of the national average (see below). Both towns also have particularly high proportions of Muslim residents $\left(24.6 \%\right.$ in Luton, $5^{\text {th }}$ nationally, and $27.0 \%$ in Blackburn, $3^{\text {rd }}$ nationally) and high rates of Muslim population growth (10.0\% between 2001 and 2011 in Luton and 7.6\% in Blackburn, compared with national average of 3.2\%).

Crucially for our purposes, while this wave of anti-minority politics initially gained momentum in Blackburn, it soon stalled. Several Blackburn residents became active in the EDL and in April 2011 the EDL held one of its largest demonstrations in the town, attracting an estimated 2,000 supporters. However, the demonstration occasioned a violent clash between Robinson and a local activist, allegedly over that activist's extreme right views, which exacerbated tensions between the Blackburn group and national leadership. Many local activists subsequently swapped allegiance to emergent splinter groups including the NWI and the English Volunteer Force (EVF). Since then anti-minority activism in the town has become more localised and sporadic. While the local authority, police and community representatives continued to treat the issue seriously, it was generally described as a problem that had been contained and they expressed confidence that prominent activists were perceived locally as 'ring-leaders' rather than 'community leaders' (B13 community worker) - a view borne-out in community focus groups.

What makes this comparison particularly intriguing is that, historically, antiminority politics had greater traction in Blackburn than in Luton. Groups at the forefront

\footnotetext{
${ }^{12}$ https://census.ukdataservice.ac.uk/media/215841/Calculating_2001_deprivation.pdf [Accessed 07/07/17] for the Carstairs Index methodology.
} 
of previous waves of anti-minority politics, including the National Front (NF) and BNP, have consistently struggled to build support in Luton. In contrast, such groups have previously achieved a modicum of success in Blackburn. The BNP gained a councillor in 2002 and, four years later, two England First Party (EFP) councillors were elected. Prior to this, in the 1970s Blackburn had one of the more active branches of the NF and a breakaway faction, the National Party (NP), had two councillors elected in 1976, narrowly missing a third. Why then did this most recent wave of anti-minority politics take root and gain greater purchase in Luton than in Blackburn?

Beyond this, two further considerations contributed to Blackburn's eventual selection. First, local authority actors in Blackburn offered to support the research. Second, members of the network that commissioned the study expressed a strong preference that the second case study should be in the north of England since Luton is in the southeast.

\section{Methods}

The research combined quantitative and qualitative methods. Since the EDL does not contend elections, there are no quantifiable locality-specific support markers for them. Where quantitative strategies could be used, however, was to analyse the demographic and socio-economic contexts and the relationship between demographic change and area scores on cohesion and local political efficacy - factors identified elsewhere as relevant to patterns of support for anti-minority politics (Kauffman \& Harris 2015, Wilks-Heeg 2010).

Datasets were created from the 1991, 2001 and 2011 Office of National Statistics censuses, capturing demographic and socio-economic indicators including self-identified 
ethnic group, religious belief and country of birth. Overall diversity levels were measured using Simpson's Diversity Index. An Index of Dissimilarity was calculated for Asian heritage groups and the Muslim population to capture segregation.

Residents Surveys (2012-2013) were pooled to create a dataset relating to perceptions of cohesion and local political efficacy. The respective questions were: 'To what extent do you agree or disagree that your local area is a place where people from different backgrounds get on well together?' and 'Do you agree or disagree that you can influence decisions affecting your local area?' Total sample sizes were 2,207 for Luton and 2,251 in Blackburn. Answers were collapsed from a Likert scale giving summary scores for both questions. ${ }^{13}$

The qualitative data comprised 44 key informant interviews (23 in Blackburn, 21 in Luton), community focus groups (6 in Blackburn, 5 in Luton) and informal discussions with relevant policy practitioners and community groups over approximately one year. Key informants included council officers, police officers, councillors, community workers, youth workers, teachers, interfaith workers and community activists. They were initially identified through liaison with council officers and, subsequently, by snowball sampling. In Luton key informants included EDL activists. Contact was made with EDL/NWI activists in Blackburn but the interviews fell through. ${ }^{14}$ We do not assess that this is a significant limitation to the study given our focus on the purchase achieved by anti-minority activists, rather than on the motivations of individual activists; the range of other interviews and focus groups undertaken; and the research team's detailed

\footnotetext{
13 The Residents' Surveys are annual surveys run by professional market research companies subcontracted by each local authority.

${ }^{14}$ Likely associated with legal proceedings against prominent local activists taking place at the time of data collection.
} 
knowledge of this protest scene nationally (Author A 2013; 2015, 2017; Authors C and A 2015). Interviewees were asked to describe their personal experience of participating in, managing, or responding to this wave of anti-minority activism.

Focus groups comprised 3-12 people. In Luton, two focus groups involved EDL supporters. The remainder encompassed local residents, organised with assistance from community workers. In both towns, focus groups were held in three areas known to have been targeted for recruitment by the EDL and cognate groups. Focus groups were divided by age: teenagers/young adults and older adults. Discussions encompassed general feelings about the local area; how people from different backgrounds get on with one another; and experiences of and attitudes towards groups like the EDL.

A timeline of events was developed based on key-word searches of local news websites, blogs, social media platforms, activist memoirs and academic publications. Approximately 25 key words were used to retrieve information from the news websites. Timelines were subsequently developed iteratively through the interviews and focus groups, enabling us to document local issues, grievances and events that respondents identified as salient.

Data were coded initially to the four sets of variables mentioned above, derived from the existing literature on patterns of anti-minority politics. A secondary set of codes was then developed relating to each set of variables, coding up from the data to identify variation between the two case studies and develop emerging hypotheses about how differences across the case study towns might relate to the observed trajectories of antiminority politics. Emerging hypotheses were iteratively refined through discussions within the research team and presentations to policy and practitioner audiences with detailed knowledge of the case study towns. 


\section{Research findings and discussion}

We organise the discussion around the four sets of variables set out above: potential catalytic events; socio-economic and political conditions; the local processes of antiminority mobilisation; and the actions of those who sought to manage or inhibit this wave of anti-minority politics. Our intention is to explore the contingency of the relationship between each set of variables and the trajectory of anti-minority activism in the two towns, demonstrating in doing so how the concept of situated credibility contests can help us to articulate these contingencies.

\section{The catalytic event}

The obvious starting point for an explanation of why and how Luton became a focal point for this wave of anti-minority politics is that it was the site of the March 2009 ASWJ protest. This event undoubtedly provided a 'moral shock' (Jasper \& Poulsen 1995), generating outrage that precipitated the initial UPL protests that laid the foundation for the EDL. As one individual involved in those events recalled,

It was that defining moment, that sort of moment of, like, 'We need to do something. That's it. I don't care what it is, that's it. Let's do something.' (L12, EDL activist).

That these events happened in Luton helped to ensure that Luton-based activists were prominent within this emergent movement and that, for EDL activists and supporters, the town became a site of enduring national and international symbolic 
importance as 'the place where it all began', ${ }^{15}$ facilitating subsequent efforts by Lutonbased activists to attract support and media attention.

Newspaper outrage attests to the symbolic potency of this event. Stopping short of violent attacks, it is hard to imagine more provocative images for much of the British public than Al-Qaeda (AQ)-inspired extremists standing in front of a war memorial holding placards besmirching British soldiers as 'Butchers of Basra' and facing-off with horrified military veterans. They provided an ideal 'condensing symbol' (Jasper 2007, 176) for the 'clash of civilisations' narratives that became central to the EDL's claimmaking (Copsey 2010). EDL activists repeatedly used the fact that police protected ASWJ activists, while members of the Luton public opposing them found themselves facing public disorder charges, to support claims about unfairness and public authority bias.

Yet elements of contingency soon emerge. Luton was not the only town to experience provocative actions by radical Islamist activists around this time, whether in the form of anti-UK or anti-democracy protests, public conversion ceremonies or public proclamations celebrating the feats of AQ (Wiktorowicz 2005) Indeed, a similar demonstration took place in Barking, East London, in June 2010. Blackburn, meanwhile, was not without its potentially catalytic events. These included potentially volatile allegations regarding the 'grooming' of white girls by Muslim men - allegations similar to those that, in towns like Rotherham and Rochdale, were associated with a significant and enduring increase in anti-minority activism. ${ }^{16}$ Yet attempts by anti-minority activists in Blackburn to exploit the symbolic potency of this breaking news story largely fell flat.

\footnotetext{
${ }^{15}$ A by-line used to promote subsequent EDL demonstrations in Luton.

${ }^{16}$ Rotherham has experienced sixteen demonstrations since 2012 , which have cost over $£ 4$ million to police http://www.bbc.com/news/uk-england-south-yorkshire-39041084
} 
So what made the Luton ASWJ protest a more effective catalyst than other similarly provocative actions by AQ-inspired activists? And why were the 'grooming' allegations in Blackburn not as effective a catalyst for organized anti-minority activism as they were in other towns? Part of the explanation might lie in the timing of events. The first instance of any form of event is likely to attract greater media attention and provoke stronger emotional responses than subsequent cases (Collins 2001). The Barking protest may have attracted less attention and generated less outrage because it simply replicated what had happened in Luton; and in the case of the grooming allegations, national media attention was already focused upon cases in towns such as Rotherham and Rochdale. Furthermore, in Blackburn's case, when the grooming allegations emerged the organisational capabilities of the local anti-minority protest scene were severely curtailed because several prominent activists happened to be incarcerated (below).

A fuller and more satisfactory explanation however requires consideration of how these events related to the wider socio-economic and political situations in the two towns, and how anti-minority activists and their opponents responded to these events and to each other's attempts to frame these events in ways consonant with their interpretations of the world and their emergent interests.

\section{The social and political context}

So what aspects of Luton's socio-political context in 2009 might have helped to make the ASWJ protest a particularly effective catalyst? One striking characteristic of Luton is the pace and distribution of demographic change. While both Luton and Blackburn have experienced demographic change at well above the national average, the rate of change in Luton is particularly rapid - greater than almost any local authority outside Greater 
London (Figure 1, appendix). The combined minority share of the population in Luton now exceeds that of the white British population share, making Luton, like Leicester and Slough, a majority minority town. There are also noteworthy differences in the distribution of demographic change. While Blackburn has several wards that remain relatively unchanged demographically (nine out of twenty-three are still over $90 \%$ White British) in Luton only three of nineteen wards are over $70 \%$ White British. While a substantial proportion of Blackburn is yet to have direct experience of demographic change, the same cannot be said in Luton.

Since previous research shows a correlation between the rate of demographic change and electoral support for anti-minority politics (Bowyer 2008; Kaufmann \& Harris 2015), local authority level ethnic diversity and opposition to immigration (Kaufmann \& Harris 2015), and ward level growth in the minority population share and BNP support (Bowyer 2008; Ford and Goodwin 2010), it might be argued that the patterns of demographic change in Luton were particularly favourable to a surge in antiminority politics.

What also stood out from local Residents' Surveys was that levels of perceived political efficacy among white UK-born residents in Luton were particularly low: $51 \%$ say they have no or little say in local decision-making, as compared with $42 \%$ in Blackburn. These perceptions might have played into the hands of anti-minority activists since the EDL, like earlier anti-minority groups (Wilks-Heeg 2010; Rhodes 2009), claim to speak for the concerns of those supposedly ignored by the 'liberal elites', appealing to disenchantment with established political parties among economically and socially marginal populations (Winlow, Hall \& Treadwell 2017).

We found several reasons to be cautious about leaning too heavily on explanations based on these variables, however. We found no evidence that concerns about 
immigration or diversity were more intense or widespread in Luton than in Blackburn, ${ }^{17}$ and as identified above, until as recently as 2006/7 organised anti-minority politics had achieved greater traction in Blackburn than Luton. Furthermore, the qualitative data indicated that, while perceived self-efficacy among white British residents might be higher in Blackburn overall, there are several neighbourhoods where the default position is one of deep scepticism about whether the public authorities listen to 'people like us'.

We also identified a third aspect of the social and political context as potentially relevant to recent trajectories of anti-minority activism in the two towns. This related to the alignment of these events with prior narratives about local social relations. Of note in Luton was the consistency with which interviewees, whether from the council, police, civil society or the anti-Muslim protest scene, emphasised that the ASWJ protest was an incident that 'magnified all the other issues' (L03 community worker) or was 'a catalyst for what's been brewing for some time' (L09 community worker). None referred to it as a starting point; a subtle but important difference.

Luton respondents consistently situated the ASWJ protest and subsequent events within narratives of a much longer and largely sub-political struggle in the town, in some cases stretching back to gang fights in the 1980s between the mainly Asian-heritage Bury Park Youth Posse and the predominantly white Farley Hill Boys. To some extent these narratives were woven around generalised claims of 'unfairness' similar to those found in other towns, including Blackburn, where anti-minority activism has periodically gained traction (Cockburn 2007; Hewitt 2005; Thomas et al 2017) - that the council

\footnotetext{
${ }^{17}$ The percentage of white UK-born residents who disagree that their local area is 'a place where people from different backgrounds get on well together' was higher in Blackburn (23.8\%) than in Luton (16.4\%), although this might reflect a difference in how the question was worded in the respective surveys: in Blackburn it specified 'Blackburn with Darwen', while in Luton it was 'your local area'.
} 
offered more support to Muslim cultural festivals than St. George's Day parades; that the police had not tackled 'Muslim heroin dealers' for fear of being labelled racist; that Muslim councillors allowed their relatives to abuse planning regulations; and even that street signage rules were applied more leniently in 'Muslim' areas. Such arguments were spun around and, in the minds of some respondents, given credence by, well-known local incidents, including the 1995 murder of Mark Sharp, a young white man killed by Asianheritage youths; an incident in October 2001 in which 15-20 'Asian' men marched on a public house chanting 'pro-Afghanistan slogans'18 and protracted complaints during the early 2000s that the council and the police had done too little about radical Islamist stalls in the town centre which, in what might now be interpreted as a precursor to the formation of the EDL, culminated in 2004 with a group of local residents, including Robinson, staging a 'ban the Luton Taliban' march. ${ }^{19}$

What also gave credence to the idea that the ASWJ protest was 'a catalyst for what's been brewing for some time' was the strength of Luton's prior association with radical Islamist networks and its prominence within the local and national collective conscience in this regard. During the 1990s and early 2000s the town was a hub for AlMuhajiroun: a regular stop for Islamist clerics such as Omar Bakri and Abu Hamza (O’Neill \& McGrory 2010). While the presence of Islamist extremist activists in Luton has subsequently diminished, partly due to the efforts of local mosques to expel such elements (Bhogal 2017), Luton has continued to feature prominently in national media discourse around these issues - several respondents recalled a Daily Mail article from

\footnotetext{
${ }^{18}$ http://www.lutontoday.co.uk/news/ignore-hoax-race-hate-stories-1-1021771 [Accessed 11/07/17]

${ }^{19}$ https://www.theguardian.com/world/2009/sep/11/english-defence-league-chaotic-alliance [Accessed $17 / 03 / 2018]$
} 
2005 that dubbed the Bury Park area 'Al Qaeda Street'. ${ }^{20}$ Periodic related news stories have contributed to the persistence of this association: in 2010 it emerged that the Stockholm bomber had spent time in town, ${ }^{21}$ and in 2013 a plot to drive a bomb into a Territorial Army centre in Luton using a remote-controlled toy car attracted national media attention. ${ }^{22}$

Other towns, including Blackburn, ${ }^{23}$ have also seen terrorism-related arrests, but few have the same length of association with radical Islamist networks or have gained such consistent prominence within national debates about AQ- or ISIS-inspired violence. Where Blackburn has featured in national media and public debates about Muslims in Britain, is in relation to the issue of segregation ${ }^{24}$ which, while of considerable policy and public concern, is not as incendiary as extremism or terrorism.

Frequent references to the particularity of Luton in the interview and focus group data support the idea that Luton's association with radical Islamist networks, amplified through national and local media and policy discourses, afforded the emergent UPL/EDL protest narrative, focused upon fears about radical Islamism and the supposed failure of the state to inhibit its functioning and growth, particular local resonance. Yet such

\footnotetext{
${ }^{20}$ http://www.independent.co.uk/news/uk/home-news/how-luton-became-the-epicentre-of-the-globalclash-of-civilisations-2159578.html and http://www.lutontoday.co.uk/news/local/fury-over-alqaeda-street-slur-1-1017839 [Accessed 18/09/2017]

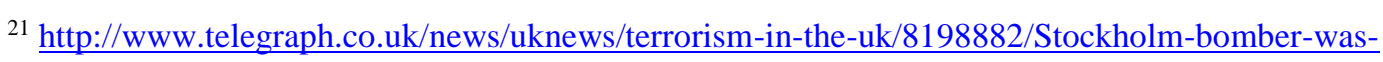
thrown-out-of-Luton-mosque-for-trying-to-recruit-extremists.html [Accessed 17/07/17]

${ }^{22}$ https://www.theguardian.com/uk/2013/apr/18/luton-terror-plot-four-jailed [Accessed 18/07/17]

${ }^{23} \mathrm{See}$ http://www.bbc.co.uk/news/uk-34423984 or http://www.telegraph.co.uk/news/uknews/terrorismin-the-uk/7482696/Blackburn-resistance-guilty-of-terrorism.html [Accessed 07/07/17]

${ }^{24}$ See the BBC Panorama investigation 'White Flight', or the furore around Jack Straw, MP's, comments about the veil http://news.bbc.co.uk/1/hi/uk_politics/5410472.stm [Accessed 18/07/2017]). Blackburn has the most segregated minority population as a whole of any local authority in England and Wales (Luton is ranked $49^{\text {th }}$ ).
} 
narrative connections, which effectively rearticulated past grievances while infusing them with hitherto unrealized significance, did not materialise out of media discourse alone. Rather, it required narrators on the ground with sufficient skill, and arguably chutzpah, to weave that narrative and to do so in a way that could mobilise public support. As one council officer in Luton put it,

Why did it happen here? Because we've got a couple of gobby characters who thought they had the balls to kick off on something that people moaned about in the pub. (L07 council officer).

It is to this issue that we now turn.

\section{Local processes of anti-minority mobilisation}

In both towns, initial mobilisation took place through dense social networks in which most individuals had multiple and often close ties. As elsewhere in the country, these included football scenes (Copsey 2010), but also family, neighbourhood and friendship networks (Busher 2015: 41-3). As the EDL gathered momentum, these networks expanded, and social and kinship networks became political networks.

Two differences between the towns stand out, however. The first is the calibre of local leaders. In Luton, even council, police and civil society respondents critical of the EDL expressed grudging respect for Robinson and Carroll as activists or opponents.

Robinson was repeatedly described as charismatic and Carroll as having 'quite a presence' (L06 police officer). The same respondents also acknowledged their political acumen, offering multiple examples of their ability to seize opportunities to 'strike a 
chord' (L06 police officer) with some segments of the public. These included a letter Robinson sent to several local authorities threatening to hold EDL marches in their towns unless Christmas celebrations were labelled thus rather than as 'winterval' celebrations; ${ }^{25}$ their support for a campaign for land in Luton to be used for affordable housing rather than a new mosque; ${ }^{26}$ scaling the FIFA building in Zurich to demand that the England football team could wear remembrance poppies, and an incident in which Robinson vaulted a barrier to punch an Islamist activist who had burned a remembrance poppy at the 2010 Remembrance Day memorial.

In Blackburn, the situation was vastly different. The local activist scene was described by police, local authority and civil society respondents as disorganised and lacking political adroitness or local cachet. There was a common view that though some young people looked up to these activists, 'outside the group there's just acceptance that they are just ex-football hooligans' (B05 council officer). This was reported even in neighbourhoods where leading activists lived and might therefore have expected to generate support through friendship and family networks (Snow et al 1986). Respondents attributed this to their violent behaviour ${ }^{27}$ and ill-judged decisions about what issues to

\footnotetext{
25 There is an annual myth, for which there is scant evidence, that councils across Britain consider rebranding Christmas festivities to avoid offending non-Christian communities http://www.huffingtonpost.co.uk/dr-chris-allen/muslim-christmas-ban_b_4464410.html

${ }^{26} \mathrm{http} / / / \mathrm{www}$. lutontoday.co.uk/news/business/drill-hall-no-longer-for-sale-1-3360965 [Accessed $31 / 10 / 2016]$

27 The EDL's association with public disorder has been identified as undermining support within low income white communities in other towns (Thomas et al 2017). While Robinson was also associated with violence, there are important differences with regards to the targeting and style of their violence: vaulting a barrier to punch somebody who has desecrated a national symbol is not equivalent to an unprovoked assault on anti-racist activists (see footnote 31 ).
} 
mobilise around and how - aside, perhaps, from a protest in a local park, ${ }^{28}$ which achieved some resonance.

An EDL protest outside a Kentucky Fried Chicken (KFC) franchise in October 2010 against the sale of halal chicken encapsulates this point. While the demonstrations, for which Bernard Holmes, one of the local leaders, dressed up in a giant chicken suit, ${ }^{29}$ succeeded in 'stirring up' some young Asian-heritage residents (B03 police officer), it generated more ridicule than respect. Local KFC customers, hungry for fried chicken, simply ignored what was described as the small and 'pretty pathetic' (B01 Police Officer) demonstration, while local media drew attention to Holmes' violent past and played on the double meaning of 'chicken', further undermining the group's credibility. ${ }^{30}$

Further reputational damage occurred in July 2011 when five 'flash protests' (see Busher 2015, 6) across East Lancashire culminated in brawls between EDL activists and Asian-heritage youths. Several activists were arrested, including Holmes who was jailed

${ }^{28}$ Queens Park became a focus for EDL activities after an Asian-heritage teenager murdered Christopher Foulkes there in 2009. The EDL sought to utilise the killing in their campaigns. In 2011, activists decided to 'reclaim' the park by playing football there on a pitch usually used by Asian-heritage youths. On one occasion, when a group of Asian-heritage youths arrived, arguments ensued, leading to the arrest of an EDL activist, who later pleaded guilty to using racially aggravated threatening behavior. The event replicated and amplified local grievance narratives. In court, the activists' lawyer stated, 'My client heard racist comments coming from the Asian males and he accepts that he responded. He says he can't understand why the police officers seemed unable to hear the comments coming from the other side.' http://www.lancashiretelegraph.co.uk/news/9142413.EDL_and_Asians_brawled_on_Blackburn_fo otball_pitches/ [Accessed 07/07/17]. http://www.thisislancashire.co.uk/news/8429843.EDL_targets_Blackburn_KFC_in_protest_over_H alal chicken/ [Accessed 07/07/17] 
for eighteen months, removing him from the local activist scene. The following July several NWI activists, including leader, Shane Calvert, were arrested and jailed for a violent assault in Liverpool. ${ }^{31}$

Local authority and police respondents in Blackburn observed that there were more adroit activists in nearby towns, who mobilised under the EVF banner in September 2013 in response to the allegations of 'grooming' in some of Blackburn's shisha bars. However, anti-racist activists, community workers and council officers reported that they had effectively undermined support for such mobilisations by portraying these individuals as outside trouble-makers - a strategy never available to those seeking to curtail EDL influence in Luton.

Another difference between Luton and Blackburn concerned activists' positioning with regards to the established extreme right. Although Robinson was briefly a BNP member around 2004, he and Carroll subsequently sought to distance the EDL from the established extreme right, organisationally and ideologically. Openly criticising the BNP and NF, they instead forged associations with actors in the counter-jihad movement, including Pamela Geller, Robert Spencer and Alan Lake (Mulhall \& Lowles 2015).

By contrast, many Blackburn activists appeared more comfortable fostering ties with extreme right groups. Indeed, this contributed to the tensions that would result in Robinson's fight with a local activist at the 2011 Blackburn demonstration. Overtly racist and extreme right slogans regularly adorn the NWI's Facebook pages and NWI activists have taken part in events organised by openly Nazi groups including National Action, banned as a 'terrorist' organisation in 2016.

\footnotetext{
${ }^{31}$ http://www.bbc.co.uk/news/uk-england-merseyside-24286583 [Accessed 08/03/2018]
} 
The explanation for this difference will undoubtedly be multi-faceted. While it might partly reflect the variation in political astuteness discussed above, it also likely reflects activists' personal mores. In the case of Robinson and Carroll, their aversion to biological racism likely reflects their socialisation within ethnically diverse social milieux - both have close friendship and family ties that span multiple ethnic backgrounds (HsiaoHung Pi 2016; Robinson 2015), which in turn might reflect the different demographic profiles of the two towns: the super-diversity of Luton with relatively low levels of ethnic segregation, compared to Blackburn, which has exceptionally high levels of segregation. Subsequently, Robinson and Carroll's ideological development was also influenced by the counter-jihad activists they encountered, who tend to eschew traditional extreme right positions on race and ethnicity.

Whatever the reasons for this difference, it is likely to have had a bearing on activists' ability to build local support. Being 'extreme right' carries a heavy stigma, even among people who may otherwise sympathise with some of the arguments and sentiments. While many local people, including some of our focus group participants, regarded the Luton EDL leadership as 'trouble-makers', unlike the Blackburn leadership they were not simply perceived, or dismissible, as racist thugs. Indeed, their efforts to distance themselves from the extreme right created opportunities for them to outmanoeuvre local opponents seeking to depict them as such (see below).

Once again, however, important contingencies emerge. Robinson and Carroll's ability to capture public and media attention was partly derived from living in a town that was of symbolic importance for the counter-jihad movement and for national debates about AQ-inspired extremism prior to the ASWJ protest; their charisma was a product of, as well as a cause for, their initial successes in mobilising support; and while they demonstrated a knack for identifying political opportunities, they developed these skills 
through action. Robinson had a reputation as a 'fixer' within football networks and Carroll was well-known within his local community, but neither they, nor people in their immediate circles, had significant experience of political organising. Some activists involved in early demonstrations admitted even copying tactics from YouTube videos of their opponents, Unite Against Fascism. Yet their position at a nodal point within nascent national and eventually international activist networks provided opportunities to learn from more skilled and experienced activists. Increased exposure to more sophisticated political ideas was accompanied by logistical support and advice (Hsiao-Hung Pi, 2016; Copsey, 2010), and a burgeoning public profile afforded Robinson and Carroll opportunities to hone their communication skills, enhancing the cachet that flowed from being the EDL founders.

The Blackburn EDL leadership also encountered more established political activists eager to take advantage of this wave of anti-minority mobilisation; including a former EFP councillor. There was, however, an important difference. While the Luton leadership came into contact and exchanged ideas with experienced, extensivelyconnected and politically astute individuals from the international counter-jihad movement, the Blackburn leaders were engaging with individuals marginal even within the British extreme right. Blackburn activists became further isolated from national and international networks after several of them formed the breakaway NWI faction in 2011. The alliances they did form drew on the most ideologically and tactically extreme factions within the wider movement, further undermining efforts to achieve public credibility.

Yet the outcome of the efforts of activists in Luton and Blackburn to position themselves as voices for disenfranchised 'ordinary English people' was also shaped by the responses of other players. 


\section{State and civil society responses}

Local authorities, police and civil society groups in both towns had, by the time our study, adopted strategies broadly similar to those of other towns facing an increase in organised anti-minority activism (Allchorn 2016). With regards to protest events, police and local authorities liaised extensively with one another, event organisers and community networks to manage events and their impacts. Meanwhile, civil society groups organised counter-demonstrations framed as celebrations of diversity in order to diminish possible confrontation, with mediators working to minimise contact between opposing activists.

In both towns, local authority actors undertook initiatives to strengthen perceptions of local political efficacy; promote positive experiences of cross-community relations; and address emergent community tensions, often building on prior community cohesion work. They declined, however, to engage with the EDL so as to avoid validating them as community spokespersons - a position informed by established anti-racist norms, personal views, and significant political pressure. The police, meanwhile, used whatever legal means they could to disrupt anti-minority activist networks. There were potentially important differences, however.

Timing and learning was a prominent theme. Luton had the misfortune to be the first town to experience this sort of mobilisation. Police, local authority and civil society respondents described struggling, initially, to understand what the UPL and then EDL was. Was it a new form of football hooliganism or a political protest? Was this another extreme right movement or something different? As one senior police officer recalled, at the time of the UPL demonstrations, Bedfordshire Constabulary, like other UK police forces, was also still adapting to new facilitation-based protest management strategies 
recommended in the 2009 Adapting to Protest ${ }^{32}$ report: 'It was all new to the police as well, all this negotiating thing, so a lot of it was guesswork' (L15 police officer). Similarly, in terms of civil society responses, when the UPL marches began, networks such as the Bury Park Contingency Group, founded to coordinate multi-agency and community-based responses, had to be 'convened quite hastily' (L09 community activist). These factors combined to make management of the first events in Luton less effective than that of subsequent events, whether in terms of public disorder, community relations or the symbolic opportunities afforded to anti-minority activists to position themselves as the victims of an oppressive state and 'political correctness', enabling antiminority activism to gain momentum locally and anti-minority activists to gain prominence.

In contrast, when Blackburn first experienced an EDL demonstration, in April 2011, considerable learning had already taken place within the police, the local authority and anti-racist groups. Demonstration management strategies, including the decision to seal off the whole demonstration area in Blackburn town centre, thereby separating the EDL from counter-demonstrators, was shaped by learning from events in nearby towns:

We had the rally at Preston... and we'd seen the footage from Bradford and Manchester that went terribly wrong. And the Blackburn demo was [according to the EDL] going to be 'bigger and better', and all this. (B01 police officer)

Anti-racist activists, local authority officers and faith networks also had more time to develop a coordinated grassroots response. Informed by the experiences of other towns,

\footnotetext{
${ }^{32}$ https://www.justiceinspectorates.gov.uk/hmicfrs/media/adapting-to-protest-nurturing-the-british-
} 
a local anti-racist network organised a defiant but non-confrontational celebration of Blackburn's diversity; Muslim community activists mobilised to discourage physical confrontation with the EDL; and neighbourhood teams and youth workers undertook extensive liaison work before and after the demonstration.

Where there is also seemingly important variation is in the alignment between the response and the type of organised anti-minority politics taking place locally. In both towns the response was informed, initially at least, by perceptions of the EDL as a combination of skinheads and football hooligans. In line with older anti-racist orthodoxy this entailed trying to police them away (i.e. making their marches miserable, wearing down local enthusiasm and morale, and placing onerous restrictions on demonstrations) whilst refusing political engagement.

In Blackburn, this response was considered to have been broadly effective. That it was effective however reflects in part the fact that the local EDL/NWI leadership validated a police-centric response by showing scant interest in engaging with formal local decision-making or dialogue. And as the NWI lurched towards ever more extreme ideological positions and tactical repertoires it did little to challenge the credibility of their characterisation as extreme right thugs.

In Luton a similar approach was less effective; arguably even counter-productive. Focus group, interview and observational data indicate that while Robinson and Carroll may have been quite widely perceived as 'troublemakers', depictions of them as 'racists' or 'Nazis' lacked credibility for many Lutonians, not least because they were known to have close and enduring friendships with prominent figures in local black and minority ethnic communities. However much race and ethnicity scholars critique the 'I've got lots of black friends' argument, it carries weight in everyday identity struggles outside academia. Furthermore, anti-minority activists in Luton did seek to engage through more 
institutionalised political channels, including community meetings and petitions. By doing so, they reconfigured the arena of contestation to their advantage. They leveraged the local authority's unwillingness to engage with them as evidence that 'ordinary people' were being ignored, and used their own interventions in community politics to position themselves as community activists and 'ordinary people' rather than 'extremists'. The credibility of such positioning has been enhanced by what they have been able to claim as victories, such as when the campaign they supported for land to be used for affordable housing rather than a new mosque was successful.

\section{Conclusion}

Our comparative case study lays bare the multiple contingencies in the relationship between potential explanatory variables and political outcomes. While the fact that Luton is home to the EDL's initial leaders is part of the story of how the town became a focal point for this wave of anti-minority activism, there might have been no EDL without the 2009 ASWJ protest, or its leaders might have hailed from elsewhere in the country. The ASWJ protest provided an effective catalyst, but this was partly a product of the ease with which it could be made to fit with existing public and media narratives about the town the incident could credibly be constructed as part of an unwelcome trend rather than an unpleasant aberration. Even then, things might have been different had, for example, Robinson and Carroll allied with the BNP rather than the counter-jihad movement; or had local authority, police and anti-racist activists in Luton not responded to the initial UPL mobilisations as if they were just another group of 'racist' or 'extreme right' 'hooligans' - a response which, while eminently comprehensible in the context of limited information and considerable public and political pressure, was nonetheless exploited by Luton's anti- 
minority activists to reinforce their claims about the exclusion of the voices of 'ordinary English people' in public debates.

We have proposed that we can pick our way through these contingencies by thinking of anti-minority activists and their opponents as engaged in a series of situated credibility contests. The more successes that anti-minority activists achieve within these contests, the more likely they are to gain traction and the more likely the town is to become a focal point for anti-minority politics. Luton's anti-minority activists achieved the traction they did because their claims to be voices of 'ordinary English people' achieved at least some credibility with local, national and international audiences: they repeatedly mobilised around issues that resonated with, and served to amplify, local, national and international narratives about the town, and sought to distance themselves from the extreme right, while undermining the credibility of the local authorities by pointing to their supposed failure to address AQ/ISIS-inspired extremism and arguing that their response to the UPL/EDL was symptomatic of their disregard for the concerns of 'ordinary English people'. By contrast, the activities of Blackburn's activists were poorly aligned with the local zeitgeist and their reputation for violence, combined with their association with extreme right activities, made it relatively easy for their opponents to frame them as 'troublemakers' or 'ring-leaders' rather than 'community leaders'. When more adroit activists came to Blackburn from other towns, their credibility was undermined by positioning them as more interested in 'stirring things up' than improving the welfare of people in Blackburn.

Further comparative time-series analysis of such contests is required to add definition to the concept of situated credibility contests and develop and test formal hypotheses: how, for example, do we conceive of locality-relevant audiences in a digital age? Is it possible to specify a relationship between the geographic distribution of 
catalytic events and leadership of anti-minority groups? Even at this early stage however we believe the concept offers an effective thinking tool for understanding cross-locality variation in the levels and persistence of traction achieved by anti-minority activism. Like other explanations of anti-minority politics, it invites analysis of demand-side and supplyside factors. However, rather than treating them as complementary but essentially distinct explanations, it stimulates analysis of how they interact through players' strategic choices over time. The primary focus on the contest encourages an important analytic rebalancing: rather than treating the actions of state actors and mainstream political parties essentially as contextual variables for anti-minority politics, they are seen as dynamic players in the contest. Finally, the concept also enables us to retain as the centre of analytic gravity the basic idea that politics is, fundamentally, a contest of competitive credibility. 


\section{References}

Allchorn W.E.C. (2016). When Anti-Islamic Protest Comes to Town: Political Responses to the English Defence League. PhD Thesis, University of Leeds, UK.

Bhogal, G.S. (2017). The Hate Factory. Online Essay.

https://medium.com/@G_S_Bhogal/the-hate-factory-part-1-6135c9b16a1 [Accessed $12 / 03 / 18]$

Biggs, M. and Knauss, S. (2012). Explaining Membership in the British National Party: A Multilevel Analysis of Contact and Threat.' European Sociological Review, 28(5), $633-646$.

Blee, K.M. (2003). Inside Organized Racism: Women in the Hate Movement. Paperback Edition. Berkeley: University of California Press.

Bowyer, B. (2008). 'Local context and extreme right support in England: the British National Party in the 2002 and 2003 local elections.' Electoral Studies, 27(4), 611-20.

Busher, J. (2015). The Making of Anti-Muslim Protest: Grassroots Activism in the English Defence League. Abingdon: Routledge.

Busher, J. (2017). Why Even Misleading Identity Claims Matter: The Evolution of the English Defence League. Political Studies 
Caiani, M. and Borri, R. (2013). 'The Extreme Right, Violence and Other Action Repertoires: An Empirical Study on Two European Countries.' Perspectives on European Politics and Society, 14(4), 562-581.

Caiani, M., della Porta, D., and Wagemann, C. (2012). Mobilizing on the Extreme Right: Germany, Italy, and the United States. Oxford: Oxford University Press.

Cockburn, T. (2007). 'Performing racism: engaging young supporters of the far right in England', British Journal of Sociology of Education, 28(5), 547-560.

Collins, R. (2001). 'Social Movements and the Focus of Emotional Attention.' In Passionate Politics: Emotions and Social Movements, edited by J. Goodwin, J.M. Jasper and F. Polletta, 27-44. Chicago: Chicago University Press.

Copsey, N. (2010). The English Defence League: Challenging Our Country and Our Values of Social Inclusion, Fairness and Equality. London: Faith Matters.

Ford, R. and Goodwin, M. (2010). 'Angry White Men: Individual and Contextual Predictors of Support for the British National Party’. Political Studies, 58(1), 11-25.

Gieryn, T. (1999). Cultural Boundaries of Science: Credibility on the Line. Chicago: Chicago University Press.

Golder, M. (2016). 'Far Right Parties in Europe.' Annual Review of Political Science, 19, 477-97 
Goodwin, M. (2006). 'The Rise and Faults of the Internalist Perspective in Extreme Right Studies.' Representation, 42(4), 347-364.

Hewitt, R. (2005). White Backlash and the Politics of Multiculturalism. Cambridge: Cambridge University Press.

Hsiao-Hung Pi (2016). Angry White People. Coming Face-to-Face with the British Far Right. London: Zed.

Husbands, C.T. (1983) Racial Exclusionism and the City: The Urban Support of the National Front. London: Allen and Unwin.

Jasper, J.M. (2007). The Art of Moral Protest: Culture, Biography and Creativity in Social Movements. Chicago, IL: University of Chicago Press

Jasper, J.M. (2015). 'Introduction: Playing the Game.' In J.M. Jasper and W.J.W Duyvendak (Eds.) (2015). Players and Arenas: The Interactive Dynamics of Protest. (pp.9-32). Chicago: University of Chicago Press.

Jasper, J.M. and Duyvendak, W.J.W. (Eds.) (2015). Players and Arenas: The Interactive Dynamics of Protest. Chicago: University of Chicago Press.

Jasper, J.M., and Poulsen, J.D. (1995). 'Recruiting Strangers and Friends: Moral Shocks and Social Networks in Animal Rights and Anti-Nuclear Protests.' Social Problems, 42(4), 493-512. 
Kaufmann, E and Harris, G. (2015). “"White Fight” or Positive Contact? Local Diversity and Attitudes to Immigration in Britain. Comparative Political Studies, 48(12), 15631590.

Klandermans, B. and Mayer, N. (Eds). (2006). Extreme Right Activists in Europe: Through the Magnifying Glass. London: Routledge.

Koopmans, R. and J. Muis (2009) 'The rise of right-wing populist Pim Fortuyn in the Netherlands: A discursive opportunity approach.' European Journal of Political Research 48(5), 642-64.

Linden, A., and Klandermans, B. (2007). 'Revolutionaries, Wanderers, Converts, and Compliants: Life Histories of Extreme Right Activists.' Journal of Contemporary Ethnography, 36(2), 184-201.

Macklin, G., and Busher, J. (2015). 'The Missing Spirals of Violence: Four Waves of Movement-Countermovement Contest in Post-War Britain. Behavioral Studies of Terrorism and Political Aggression, 7(1), 53-68.

Miller-Idriss, C. (2017). The Extreme Gone Mainstream: Commercialization and Far Right Youth Culture in Germany. Princeton: Princeton University Press.

Mudde, C. (2010). 'The Populist Radical Right: A Pathological Normalcy.' West European Politics, 33(6), 1167-1186. 
Muis, J. and T. Immerzeel (2017). 'Causes and consequences of the rise of populist radical right parties and movements in Europe.' Current Sociology Review, 65(6), 909930

Mulhall, J. and Lowles, N. (2015). The Counter-Jihad Movement: Anti-Muslim Hatred from the Margins to the Mainstream. London: Hope Not Hate.

Nye, J.S.J. (2011). The Future of Power. New York: Public Affairs.

O’Neill, S. and McGrory, D. (2010). The Suicide Factory: Abu Hamza and the Finsbury Park Mosque. London: Harper Perennial.

Pilkington, H. (2016). Loud and Proud: Passion and Politics in the English Defence League. Manchester: Manchester University Press.

Rhodes, J. (2009). 'The political breakthrough of the BNP: The case of Burnley.' British Politics, 4(1), 22-46.

Robinson, T. (2015). Enemy of the State. Batley: The Press News Ltd.

Roy, J-P. (1993) Le Front National en Région Centre (1984-1992). Paris: Harmattan.

Rydgren, J. (2007). 'The Sociology of the Radical Right.' Annual Review of Sociology, $33,241-62$ 
Seawright, J. and J. Gerring (2008). 'Case Selection Techniques in Case Study Research: A Menu of Qualitative and Quantitative Options.' Political Research Quarterly, 61(2), 294-308

Simi, P., and Futrell, R. (2010). American Swastika: Inside the White Power Movement's Hidden Spaces of Hate. Plymouth: Rowman \& Littlefield.

Snow, D.A., E.B. Rochford Jr, S.K. Worden and R.D. Benford. 1986. "Frame Alignment Processes, Micromobilization, and Movement Participation." American Sociological Review 51(4):464-481.

Thomas, P., Busher, J., Macklin, G., Rogerson, M., and Christmann, K. (2017). 'Hopes and Fears: Community cohesion and the 'White Working Class' in one of the 'Failed Spaces' of Multiculturalism.' Sociology, Online First.

Virchow, F. (2007). 'Performance, Emotion, and Ideology: On the Creation of 'Collectives of Emotion" and Worldview in the Contemporary German Far Right.' Journal of Contemporary Ethnography, 36(2), 147-164.

Wacquant, L. (1989). Towards a Reflexive Sociology: A Workshop with Pierre Bourdieu. Sociological Theory, 7(1), 26-63.

Wilks-Heeg, S (2010). 'A Slow and Painful Death? Political Parties and Local Democracy in Two Northern Towns.' Local Government Studies, 36(3), 381-2010 
Winlow, S., Hall, S., and Treadwell, J. (2017). The Rise of the Right: English Nationalism and the Transformation of Working-Class Politics. Bristol: Policy Press.

Wiktorowicz, Q. (2005) Radical Islam Rising: Muslim Extremism in the West. Lanham: Rowman \& Littlefield.

Zerubavel, E. (1999). Social Mindscapes: An Invitation to Cognitive Sociology. Cambridge, Harvard University Press. 